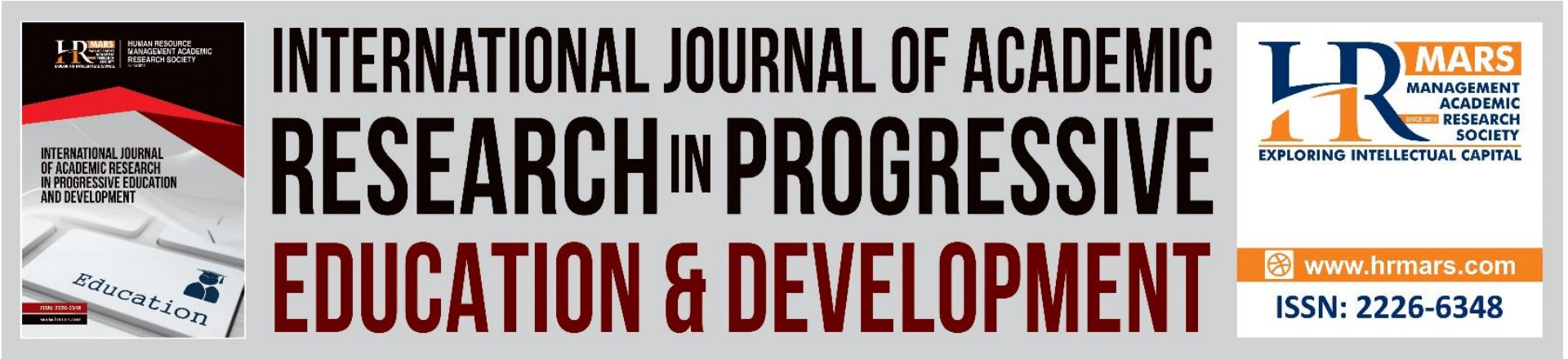

\title{
Ridding Some Books from being Attributed to Al-Hafiz Abdul Ghani Al-Maqdisi
}

\section{Ahmed Mohamed Mohamed Basuoni, Rohaizan Bin Baru}

To Link this Article: http://dx.doi.org/10.6007/IJARPED/v10-i4/11874

DOI:10.6007/IJARPED/v10-i4/11874

Received: 04 September 2021, Revised: 10 October 2021, Accepted: 27 October 2021

Published Online: 24 November 2021

In-Text Citation: (Basuoni \& Baru, 2021)

To Cite this Article: Basuoni, A. M. M., \& Baru, R. Bin. (2021). Ridding Some Books from being Attributed to AlHafiz Abdul Ghani Al-Maqdisi. International Journal of Academic Research in Progressive Education and Development, 11(12), 189-195.

Copyright: (C) 2021 The Author(s)

Published by Human Resource Management Academic Research Society (www.hrmars.com)

This article is published under the Creative Commons Attribution (CC BY 4.0) license. Anyone may reproduce, distribute, translate and create derivative works of this article (for both commercial and non-commercial purposes), subject to full attribution to the original publication and authors. The full terms of this license may be seen

at: http://creativecommons.org/licences/by/4.0/legalcode

Vol. 10(4) 2021, Pg. 189 - 195

Full Terms \& Conditions of access and use can be found at http://hrmars.com/index.php/pages/detail/publication-ethics 


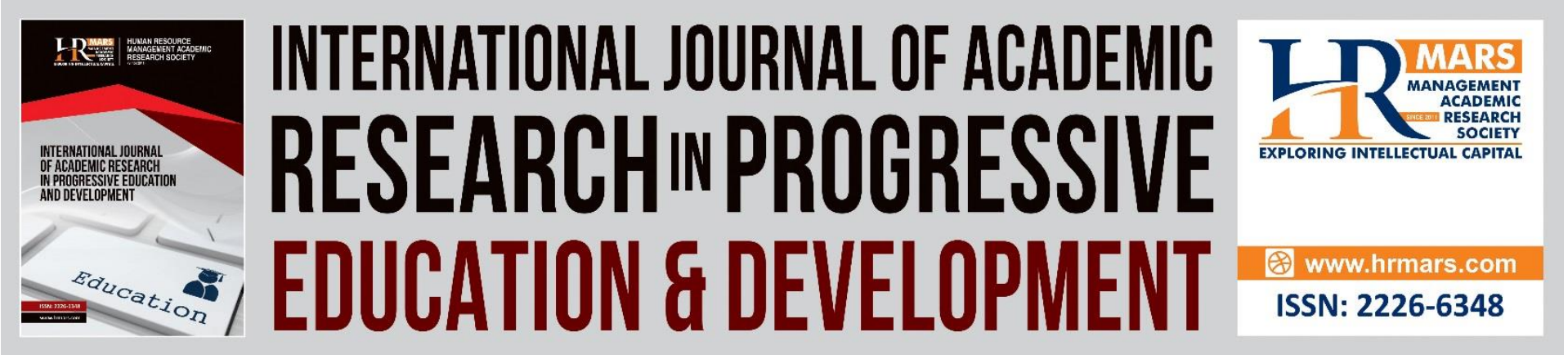

\title{
Ridding Some Books from being Attributed to Al- Hafiz Abdul Ghani Al-Maqdisi
}

\author{
Sultan Zainal Abidin University (UniSZA), Faculty of Islamic Contemporary Studies \\ (FKI), MALAYSIA \\ Corresponding Authors: ahm.amb@gmail.com
}

Ahmed Mohamed Mohamed Basuoni, Rohaizan Bin Baru

\begin{abstract}
As the attribution of some books to non-authors increased, this research was an attempt to rid some books from attribution to non-authors. This attempt was aimed at the literature attributed to one of the scholars of the 6th century AH; Al-Hafiz Abdul Ghani Al-Maqdisi. Although many of the works have been proven to him, some of them are incorrect to be attributed to him. After implementing the scientific method, the researcher proved the incorrectness of attributing some of books to him; that is after collecting his books, knowing his method of classification, and dealing with his handwriting and the way he wrote words. The researcher outlined these works, and the reasons that led to the error of attributing them to Al-Hafiz Abdul Ghani Al-Maqdisi.
\end{abstract}

Keywords: Ridding From, Abdul Ghani, Al-Maqdisi, Books, Attributed.

\section{Introduction}

Many scholars have collected and categorized the Sunnah on chapters, Masaneed (hadith collections companion-wise) and parts, and among those who did this was Al-Hafiz Abdul Ghani Al-Maqdisi (died in the year $600 \mathrm{AH}$ ), he compiled useful good books on Hadith.

\section{Preamble}

A large number of books have been attributed to non-authors, for several reasons, including: the similarity of the authors' handwritings in the handwritten copies that have reached us, the similarity of the method of classification, and the like. The attribution of books to their authors or denying their attribution to them is a painstaking matter in research and editing. Among those to whom books were attributed without writing them was Al-Hafiz Abdul Ghani Al-Maqdisi.

\section{Some Books of Al-Hafiz Abdul Ghani Al-Maqdisi}

Among his published books are: "The Biography of the Prophet, may God's prayers and peace be upon him," "Umdat Al-Ahkam min Kalam Khair Al-Anam," which is one of his most famous accepted books, "Al-Kamal fi Asma Arrijal", "Attargheeb fi Addua wa Al-Hath Alayhi" meaning (Encouragement to supplication and urging thereof), "Tahreem Al-Katl wa Ta'thimih". "Manaqib Al-Sahabiyat" meaning virtues of the Companion women, and so on. 
Among his books that have not been printed to this day, and the researcher has found many of them, were: "Al-Misbah fi Ouyune Al-Ahadith ASsihah." It did not reach us in full after diligence and research in the indexes of international libraries, and the researcher found nine parts out of forty-eight parts of the book, three parts of which are within the collections of the Omariya School in Dhahiriyya Damascus, and six parts are from the Mahmudiyah Library in Madinah. I pondered on the parts that I have perused and found that they were written in the author's handwriting, which is considered to be an extract of Sahih Al-Bukhari and Muslim; as well as the book of "Attawakkul and Su'al Allah Azza Wa Jal" (Reliance on God Almighty and Asking Him), there was a copy of it in the Dhahiriyya House of Books in Damascus, the researcher perused it and it was among a total of 164 papers 218-249. It was found by comparison and investigation that it was written in the author's handwriting.

"The Virtues of Omar Ibn Al-Khattab, may God be pleased with him." The researcher acquainted himself with the second part of it only, and has not yet found the first part following research in the indexes. The researcher found the second part within the manuscripts of Umariya School, in Dhahiriya House of Books in Damascus, collection No. (3767 general) collections [30], Message No. 4, 16 folios (68-83), in addition to many books that the researcher has checked either complete or incomplete, they are still manuscripts that have not yet been printed.

Among his lost books that were mentioned by scholars in their books, and the researcher did not find after looking and investigating through indexes, visiting some libraries, and reviewing many written originals of unknown author, are the following books: "Al-Athar AlMurdhiya fi Fadhael Khair Al-Bariyah". A group of scholars mentioned it, and they said it was a book of Hadiths in four parts. (Sibt Ibn Al-Jawzi, 2012, 22/138), (Al-Dhahabi, 1984, 21/447), (Ibn Rajab, 2004, 3/24). "The Book of Tahajjud" mentioned by a group of people, saying it was a book of Hadith in two parts. (Sibt Ibn Al-Jawzi, 2012, 22/138), (Al-Dhahabi, 1984, 21/447), (Al-Safadi, 1999, 19/22) (Ibn Rajab, 2004, 3/24).

"The Book of Signs of the Hour of Resurrection" was mentioned by a group of scholars. (AlRudani, 1987, p. 116), (Al-Kitani, 2000, p. 49). This is in addition to many missing books mentioned by scholars when translating Abdul Ghani Al-Maqdisi, and the researcher did not find these books after research and inspection.

\section{Wrongly Attributed Books to him}

With the fame of Al-Hafiz Abdul-Ghani's books, some of them have been attributed to him by mistake, for the following reasons:

Some indexes indicated some books as belonging to Al-Hafiz Abdul-Ghani and upon verification it becomes clear that they are not his, including:

- A book entitled: "A Brief Note on the Fundamentals of Jurisprudence on the School of AlImam Ahmad," attributed to Hafiz Abdul Ghani Al-Maqdisi by the same Investigator of the book of "Al-Eqtisad fi Al-Eatiqad" (Economy in Faith) by the same author, where he mentioned it among his books, saying: "A brief note on the principles of jurisprudence on the doctrine of Al-Imam Ahmed: including an illustrated copy in the Islamic University Library within the collection No. (1531)" (Al-Ghamdi, 1993, p. 38), and the researcher has seen the written copy referred to, it is preserved in the manuscripts of Dhahiriya - within the collections of Al-Umariyah Library - collection No. (3828 general) [collections 92], which is the third message, its paper: $28(16-43)$, and it turns out that the author of this book is: Badruddin Abdurrahman Ibn Al-Hafiz Abdul Al-Ghani, and the following was mentioned at the beginning of the written copy in the handwriting of Ali Ibn Muhammad Ibn Abbas al-Baali 
Al-Hanbali: "The scholar Sheikh Al-Islam Badruddin Ibn Sheikh Al-Islam Al-Hafiz Abdul-Ghani Al-Maqdisi Al-Hanbali - may God prolong his life, said-: Praise be to God, Lord of the worlds, and his prayer and blessings be upon the most honorable messengers, Muhammad, the last of the prophets, and upon his entire family and companions, a permanent prayer to the Day of Judgment. This is a brief note on the fundamentals of jurisprudence on the doctrine of the revered Imam Abi Abdullah Ahmed bin Muhammad bin Hanbal and his companions and some of the imams he agreed with them, it establishes the understanding of the beginner and revises it..." (Badruddin, manuscript, section 17), his indexing was correct in the "Index of the Groups of the Omariya School", except that he said: The author was Badruddin Ibn AlHafiz Abdul Ghani, and perhaps he meant Muhammad Ibn Abdul Ghani, who died in $613 \mathrm{AH}$. (Al-Sawas, 1987, pg. 479). The researcher said: The correct view is that he is Abdurrahman as this Muhammad is nicknamed "Izz Addin" (Sibt Ibn al-Jawzi, 2012, 22/214), and it has been confirmed in several ways, the first of which is: the author's name has been declared, and secondly: this book was not attributed by one of the great scholars in the past to Al-Hafiz Abdul-Ghani.

- A book titled "The Sixth Part of Fawaed Hissan, and the Murder of Uthman Ibn Affan, May God is pleased with him," which is part of the collection No. (3808 general) [Collections 72], and it was mentioned in the Umariyah Library index attributing to Al-Hafiz Abdul Ghani (AlSawas, 1987, p. 367), but the right thing is that it belongs to Abi Bakr Ahmed Ibn Kamil AlBaghdadi (died in $350 \mathrm{AH}$ ), it was written at the beginning of the copy: "The sixth part of Fawaed Hissan, and the Murder of Uthman Ibn Affan, may God is pleased with him, narrated by Abi Bakr Ahmed Ibn Kamil Ibn Khalaf Ibn Shajarah" (Al-Baghdadi, manuscript, s 1), and this copy bears the hearing proof to Al-Hafiz Abdul Ghani, his handwriting on the copy and his endowment thereof, and perhaps this is the reason for their mistake, and many of those who mentioned the books of Al-Hafiz Abdul Ghani have committed this mistake, including: the investigator of the book of "Al-Eqtisad fi Al-Eatiqad" meaning "Economy in Faith", where he said: the book of "Fadhael Hissan and Murder of Othman: There is a copy of it in the university library in the collection No. 563, and its origin is in Dhahiriya library" (Al-Ghamdi, 1993, pg. 40), and he called it thus: "Fadhael Hissan" meaning good virtues"!, and so did the authors of the Dictionary of The History of Islamic Heritage in the libraries of the world. They considered it among his books, may God have mercy on him. (Balout, 2001, 3/1810).

- The book of "Al-Muntaqa min Kitab al-Tabaqat", meaning (Selection from the book of AlTabaqat) which was printed in Dar Al-Bashaer - Beirut, with the investigation of: Ibrahim Saleh attributed to Abu Orouba Al-Harrani (died in $318 \mathrm{AH}$ ), but Al-Zarkali said in Al-Alam about the book of Al-Tabaqat by Abi Uruba: It was likely shortened by Abdul Ghani Ibn Abdul Wahid Al-Maqdisi

(died in the year 600), and entitled it (Muntaqa Tabaqat Abi Uruba), the second part of it (12 papers) was in Dhahiriya, Damascus. Perhaps it was the one mentioned earlier by the name (History)" (Al-Zarkali, 2002, 2/253), and by reference to the written copy mentioned, which is in Dhahiriya library with number (4553 general), I did not find anything indicating that the abbreviation belonged to Al-Hafiz Abdul Ghani, and perhaps the reason for the error is that the book bears an endowment proof in the name of Al-Hafiz Abdul-Ghani, may God have mercy on him, and the authors of the Dictionary of the History of Islamic Heritage in world libraries followed the words of Al-Zarkali, considering it among his books, may God have mercy on him. (Balout, 2001, 3/1810). 
- The book of "Hadith of Abi Bakr Al-Qutai'i and others" was attributed to him by the authors of the Dictionary of the History of Islamic Heritage in the world's libraries, as they considered it among his books, may God have mercy on him. (Balout, 2001, 3/1810), and the correct view is that it is among his narrations, and he wrote it in his own handwriting, and this part was not printed, and there is a copy of it in Dar Al-Kutub Al- Dhahiriya - Al-Umariya school within the collection number (3849 general) [collections 113], and perhaps it is part of Fawaed Abi Abdillah Al-Zanjani; containing his narrations about Al-Qutai'i, so it has to be freed from such attributions.

- The book of "Al-Asrar" and it was mentioned thus by Ibn Rajab in his book "Dhayl Tabaqat Al-Hanabilah" (Ibn Rajab, 2004, 3/24), and the book's investigator, Dr. Abdurrahman AlUthaymeen, may God have mercy on him, said in the footnote: in (a): "Al-Israa (The Night Journey)," it appears to be distorted from "Al- Ashrat (the Signs of the Hour)," so it is the same book "The Signs of the Hour" mentioned in "Al-Risalat Al-Mustatrafa" (49). The researcher said: By referring to the handwritten copy of the book Al-Dhayl by Ibn Rajab, it becomes clear that it is: Al-Israa, as the investigator indicated in the footnote, and the correct one is: it is Al-Israa, and it was mentioned as such by a group of people, (Sibt Ibn al-Jawzi, 2012, 22/138), (Al-Dhahabi, 1998, 4/112), (Al-Safadi, 1999, 19/22).

\section{Reasons for Attributing Books to Non-authors}

From the foregoing and by studying the books that were wrongly attributed to Al-Hafiz Abdul Ghani it becomes clear that there are several reasons for this, including:

1- The handwriting of the author of the book is similar to the one to whom the book is attributed.

2- The author to whom the book is attributed writes some words on the handwritten copy, such as owned by, or proof of hearing, and so on.

3- The name and subject of the book are similar to the books of the author to whom they are attributed.

4- The existence of a date on the written copy that corresponds to the life period of the author to whom the book is attributed.

5- Error in some library indexes because of the above, or that the indexer was not sufficiently experienced to determine the correct attribution.

6- Misreading what was written on the handwritten copy; either because of poor handwriting, poor photocopying, or lack of experience with calligraphies.

7- Error of those in charge of maintaining written copies, who placed the paper of the first tablet of the manuscript on another book, which leads to attributing the book to someone other than its author.

\section{Conclusion}

After going through this research, which shows the error of attributing books to non-authors, as represented by Al-Hafiz Abdul Ghani, the researcher concluded by several results, the most important of which are:

1. Incorrect attribution of the following books to Al-Hafiz Abdul-Ghani, (Tazkira Mukhtasarah fi Ousul Al-Figh (meaning a brief note on the fundamentals of jurisprudence, the sixth part of "Fawaed Hissan" Al-Muntaqa min Kitab Al-Tabaqat, the hadith of Abi Bakr Al-Qutai'i, and Al-Asrar). 
2. Existence of important books by Al-Hafiz Abdul Ghani, the manuscript of which was found, and it has not been printed yet.

3. There are multiple causes of error in attributing books to non-authors, and it is important to take them into consideration when attributing a book to a particular author.

4. Importance of the skill of experienced researcher in knowing the causes and possibilities of error in order to achieve the correct attribution.

\section{References}

The Holy Quran

Abdelgelil, M. F. M. (2020). Grammarians' Critique of Qur'anic Qira'at. International Journal of Academic Research in Business and Social Sciences, 10(11), 1225-1231. Abdelgelil, M. F. M. (2020). Solving the Quranic Issues with Quranic Qira'at, International Journal of Academic Research in Business and Social Sciences, 10(12), 36-42.

Abdelgelil, M. F. M., Al-Janayni, M. U., Baru, R., Hamzah, M. S., Razali, M. A. T. M., \& Ismail, F. Z. (2018). Tawjih Al-Qira'at Based on Inscription, Language, and Unusual Modes of Recitation According to Ibn Zanjalah. International Journal of Academic Research in Business and Social Sciences, 8(10), 362-370.

Abdelgelil, M. F. M., Alshaheri, Y. M. A., Subagio, M. H. M., Hassan, A. F., Othman, A. K. I., \& Omar, N. (2021). The Languages of the Arabs and Their Relationship to The Qiraat in The Interpretation of Ibn Ajiba. International Journal of Academic Research in Business and Social Sciences, 11(9), 759-765.

Abdelgelil, M. F. M., Daud, N. B., Omar, N. B., Ismail, F. Z. B., \& Wahab, A. H. B. A. (2018). Taujeeh Al-Qira'at Using Qur'an, Hadith and Poetry according to Ibn Zanjalah. International Journal of Academic Research in Business and Social Sciences, 8(10), 371-379.

Abdelgelil, M. F. M., Hasan, A. F., Yusoh, F, El khayat, M. H. M., Razali, M. A., Ismail, F. Z., \& Ab Rashid, R. (2021). Correlation Between Irregular Qiraat And Arabic Linguistics In The Quranic Tafseer Book By Al-Razi. International Journal of Academic Research in Business and Social Sciences, 11(7), 1632-1639.

Abdelgelil, M. F. M., Hasan, A. F., Yusoh, F., Ismail, F. Z., Ab Rashid, R., Ab Aziz, N. S., Hassan, A (2021). The Impact of Irregular Qiraat on Arabic Semantics and Dialects. International Journal of Academic Research in Business and Social Sciences, 11(7), 1672-1676.

Abdelgelil, M. F. M., Hasan. A. F., Yusoh, F., El khayat, M. H. M., Razali, M. A., Hassan, A., Ab Aziz, N. S. (2021). Arabic Syntactic Rules with Reference to Quranic Qurra. International Journal of Academic Research in Business and Social Sciences, 11(7), 1707-1711.

Abdelgelil, M. F. M., Hassan, A., Yusof, N. H., Idris, M. F. H., Hasan, A. F., \& Ramadan, A. A. (2020). Defending the Quran in the Study of Tawjeeh Al-Qira'at, International Journal of Management, 11(10), pp. 101-104.

Abdelgelil, M. F. M., Musolin, M. H., Serour, R. O. H., Abdullah, M. S., \& Noor, M. N. M. (2018). Law and Moral Values in the Holy Quran. International Journal of Academic Research in Business and Social Sciences, 8(11), 445-451.

Abdelgelil, M. F. M., Osman, M. F. M. A., Serour, R. O. H., Subagio, M. H. M., Othman, A. K. I., \& Hassan, A. F. (2021). The History of the Qur'anic Enigma and the Impact of Interpretation in Directing it. International Journal of Academic Research in Progressive Education and Development, 10(3), 412-418. 
Abdelgelil, M. F. M., Othman, A. K. I., Serour, R. O. H., Osman, M. F. M. A., \& Hassan, A. F. (2021). Ibn Qutayba's Response to the Slanderers who Claim Grammatical Mistake in the Qur'an. International Journal of Academic Research in Progressive Education and Development, 10(3), 419-426.

Abdelgelil, M. F. M., Othman, A. K. I., Subagio, M. H. M., Serour, R. O. H., Hassan, A. F., \& Osman, M. F. M. A. (2021). Directing the Enigma of Quranic Words According to Ibn Qutaybah and Al-Far. International Journal of Academic Research in Progressive Education and Development, 10(3), 427-434.

Abdelgelil, M. F. M., Razali, M. A., Hassan, A., Hasan, A. F., Idris, M. F. H., \& Masoud, A. S. (2020). Quranic Inimitability in Quranic Qiraat, International Journal of Management, 11(10), pp. 117-121.

Abu Uruba, A. M. A. (1994). Hadiths on Poetry. Investigation: Ibrahim Saleh. Beirut: Dar AlBashaer.

Al-Baghdadi, A. K. (N. D). the sixth part of Fawaed Hissan and the killing of Uthman Ibn Affan. may God be pleased with him, Syria: manuscript in the Umariya Library of AlDhahiriyah, Syria.

Al-Dhahabi, M. A. Q. (1984). Siyar Alam Al-Nubala', Investigation: A group of investigators under the supervision of Shoaib Arnaout. Beirut: Al-Resala Foundation.

Al-Dhahabi, M. A. Q. (1998). Tazkirat Al-Huffaz. Beirut: Dar Al-Kutub Al-Ilmiyya.

Al-Kitani, M. A. (2003). Al-Resalah Al-Mustatrafa libayan Mashour Kutub Assunna AlMusharrafah. Investigation: Muhammad Al-Muntasir Ibn Muhammad Al-Zamzami. Beirut: Dar Al-Bashaer Al-Islamiyyah.

Al-Maqdisi, A. A. (1993). Al-Eqtisad fi Al-Eatiqad. Investigation: Ahmed Ibn Attiya Ibn Ali AlGhamdi. Medina: Library of Science and Wisdom.

Al-Maqdisi, A. A. (N. D). the second of the virtues of Umar Ibn Al-Khattab, Syria: manuscript in the Umariya Library of Dhahiriya.

Al-Qutai'i, A. J. H. (N. D). the hadith of Abi Bakr Al-Qutai'i and others. Syria: manuscript in the Umariya Library of Al-Dhahiriyah.

Al-Rudani, M. M. S. (1987). Silat Al-Khalaf Bimawsool Al-Salaf. Investigation: Muhammad Hajji. Beirut: Dar Al-Gharb Al-Islami.

Al-Sawas, Y. M. (1987). Index of the collections of the Umariya School in Dar al-Kutub AlDhahiriyah in Damascus. Kuwait: Institute of Arabic Manuscripts.

Al-Zarkali, K. M. D. (2002). Al-Alam. Beirut: Dar Alelm Lilmalayin.

Badruddin, A. A. (N. D). a brief note on the fundamentals of jurisprudence on the doctrine of Al-Imam Ahmad, Syria: manuscript in the Umariya Library of Dhahiriya.

Ballout, A. K. (2001). Dictionary of the History of Islamic Heritage in the Libraries of the World (Manuscripts and Publications). Turkey: Dar Al-Aqaba.

Ibn Rajab, A. A. (2004). Al-Dhayl Tabaqat Al-Hanabilah. Riyadh: Al-Obaikan Library

Sibt Ibn al-Jawzi, Y. (2012). Mira't Azzaman fi Tawareekh Al-Ayan. Investigation: A group of investigators. Syria: Dar Al-Resala Al-Alameya. 